\title{
Kételyek és megoldások. Megoldások és kételyek
}

\section{A Covid-19-járvány gazdasági következményei}

Nem lehet kétségünk afelöl, hogy az epidemiológiai hatásokon túl, a koronavírus-járványnak számos társadalmi és gazdasági következménye lesz. Ezeknek egy részét már ismerjük. Az első hullámban hozott, a vírus terjedését korlátozó kormányzati intézkedések gazdaságra gyakorolt hatása néhány szempontból már ma is értékelhető. Az Eurostat részben becsléseken alapuló állásfoglalása szerint, az Európai Unióban 2020. második negyedévében a GDP nagyságrendileg 12, illetve 15\%-kal csökkent a megelöző negyedévhez, valamint az előző év azonos időszakához képest. Magyarországon, a kezdeti várakozásokat érdemben meghaladva, ez a két adat 14,5 és 13,5\%-os visszaesést mutatott. Emellett, a KSH közlése szerint a beruházások az előzó év azonos időszakától 9,9\%-kal maradtak el, a feldolgozóiparban $(-10,4 \%)$ és a kereskedelemben $(-12,5 \%)$ pedig az átlagot is meghaladó mértékü volt a visszaesés. A Nemzeti Foglalkoztatási Szolgálat adatai szerint júniusban a regisztrált álláskeresők száma 376 ezer fö volt, ami 128 ezerrel több, mint egy évvel korábban.

Ebből a néhány fenti kiragadott adatból is látható, hogy míg a vírus terjedésének megakadályozására a március-áprilisban érzékelt zárás megfelelő volt, addig a gazdasági kontinuitást érdemben korlátozta, és komoly hatással volt a gazdasági aktivitás alakulására. A recept e tekintetben egyértelmünek tünik, a továbbiakban, az első hullám időszakában - a vírus teljes ismeretlensége indokán - bevezetett korlátozó intézkedések egy részét szükségszerü lenne elkerülni. (Minden bizonnyal idetartozik az iskolák és a kereskedelmi egységek bezárása.) Az elsődleges cél továbbra is a terjedés megakadályozása, de csak oly módon, hogy annak a nem szándékolt következményei minimálisak legyenek, és a korlátozó intézkedések társadalmi költsége elfogadható mértékü maradjon. Egyensúlyozásra van tehát szükség a terjedés megakadályozása és a gazdasági aktivitás korlátozása között.

A szükségszerű korlátozásokkal egyidőben pedig a döntéshozói figyelmet a gazdaság talpra állítására szükséges fordítani. Júliusban, a több napon át tartó tárgyalássorozatukat követően az uniós vezetők megállapodtak a szükséges helyreállítási tervről, és ehhez a hagyományos költségvetést kiegészítendő, egy 750 milliárd euró keretösszegü programot fogadtak el. A Next Generation EU nevezetű program első látásra ambiciózusnak tűnik, a kulcskérdés azonban az, hogy az egyes tagállamok milyen eredményekkel fogják tudni felhasználni a program biztosította forrásokat. Ursula von der Leyen elnökasszony a helyreállítási terv és a 2021-2027-es ciklusra érvényes költségvetés elfogadását követően azt nyilatkozta, hogy „a megállapodás a bizalom erős jele és történelmi pillanat Európa számára”. Abban biztosan egyetértünk, hogy valamennyi válságkezelési folyamat egyik legfontosabb feladata a bizalom fenntartása és annak a képességnek a hangsúlyozása, hogy

Felméry Zoltán, a Budapesti Corvinus Egyetem, Stratégiai és Projektvezetés Tanszék tudományos segédmunkatársa, a Nemzeti Közszolgálati Egyetem, SVKI tudományos munkatársa, e-mail: felmery.zoltan@gmail.com 
a közösség képes úrrá lenni a válságon. A 2008-as pénzügyi válság során láthattuk, hogy a rendszerszintü bizalmatlanság mennyire megnehezíti és megdrágítja a válságkezelést. Ez reméljük, most elkerülhetö lesz. 